\title{
FASHION AND PATTERN DESIGN OF LADIES' DRESSES WITH TRANSFORMATION OF DIFFERENT TYPES OF DRAPERIES
}

\author{
Zlatina Kazlacheva, Julieta llieva, Tanya Peneva \\ Faculty of Technics and Technologies of Yambol, \\ Trakia University, Bulgaria \\ Graf Ignatiev 38, 8600 Yambol, Bulgaria \\ e-mail: zlatinka.kazlacheva@trakia-uni.bg
}

\begin{abstract}
One of the ways of creation of new fashion designs is the transformation of a garment in another one. According to the main design principles silhouettes, lines, and forms of elements and pieces can be changed. According to both fashion and technical design the change of the elements with decorative and constructive function is more important than changing only decorative ones. The transformations are possible for all of elements with decorative and constructive function: darts, seams, 3D elements. And according to the fashion and pattern making view the drapery is maybe the most interesting three dimensional element, which can be with only decorative, but in the more of the cases it is with decorative and constructive function. The paper presents fashion and pattern design of ladies' dresses on the base of transformation of the three basic types of drapes: twist knot, twisted and free draperies. In created variants draperies are with decorative and constructive function. With presented way of transformation new designs of draped ladies' dresses are easy and successfully created. Every of the basic three types of drapery with decorative and constructive function: twist knot, twisted and free ones can be changed with other two types. The facilitating of design and pattern making is result not only that transformations are made on one basic model, but also that systemized approaches of constructing of twist knot and twisted draperies are used.
\end{abstract}

Keywords: fashion design, pattern making, drapery, twist knot drape, twisted drapery.

\section{INTRODUCTION}

One of the ways of creation of new fashion designs is the transformation of a garment in another one. According to the main design principles silhouettes, lines, and forms of elements and pieces can be changed. According to both fashion and technical design the change of the elements with decorative and constructive function is more important than changing only decorative ones. The transformations are possible for all of elements with decorative and constructive function: darts, seams, 3D elements. And according to the fashion and pattern making view the drapery is maybe the most interesting three dimensional element, which can be with only decorative, but in the more of the cases it is with decorative and constructive function.

The paper presents fashion and pattern design of ladies' dresses on the base of transformation of the three basic types of drapes: twist knot, twisted and free draperies. In created variants draperies are with decorative and constructive function.

\section{FASHION AND PATTERN DESIGN OF A LADY'S DRESS WITH TWIST KNOT DRAPERY}

Figure 1 presents a lady' dress design with a twist knot drapery [1]. The knot is situated asymmetrically and divides the neck opening in a proportion equal to the Golden ratio [2]. Pattern design of the dress is shown in Figures 2 and 3.

IRTIIE Vol. 7, No. 1, 2019 ISSN 1314-8788 (print), ISSN 1314-8796 (online), doi: 10.15547/artte.2019.01.002 


\section{IRTIIE}

(

Ipplied Resseirlohes in Technics, Technologies and Eductition

Journal of the Faculty of Technics and Technologies, Trakia University https://sites.google.com/a/trakia-uni.bg/artte/

In [1] an investigation of measurements of this type drapery is presented. The study is realized only for ladies' clothing, which is made from woven fabrics. Using the results of the investigation a systemized approach of pattern making is developed on the base of the pattern design approach of Tomoko Nakamichi [3]. The systemization is a result of obtaining of formulas (1) and (2) with linear regressions [4]. With a dependence the width of the draped pieces in the place of twist is determined on the base of the diameter of the knot - formula (1) [1], or with a dependence the diameter of the knot is determined on the base of the width of the draped pieces in the place of twist - formula (2) [1]:

$$
\begin{aligned}
& W=5,15 . D-4,4, \\
& D=0,2 \cdot W+0,85,
\end{aligned}
$$

where $\mathrm{W}, \mathrm{cm}$ is the width of the draped pieces in the place of twist; $\mathrm{D}, \mathrm{cm}$ - the diameter of the knot.

The use of formula (1) or (2) depends on the fashion design.

In presented design the drapery has to be in harmony with of the Golden section proportion, which determines the place of the twist knot in the neckline. By this reason not too volume and intensive drape folds are chosen and the width of the draped pieces in the place of twist $W=16,5 \mathrm{~cm}$, which is the smaller size in investigation shown in [1]. The diameter of the knot $\mathrm{D}=4,15 \mathrm{~cm}$ is determined by dependence (2).

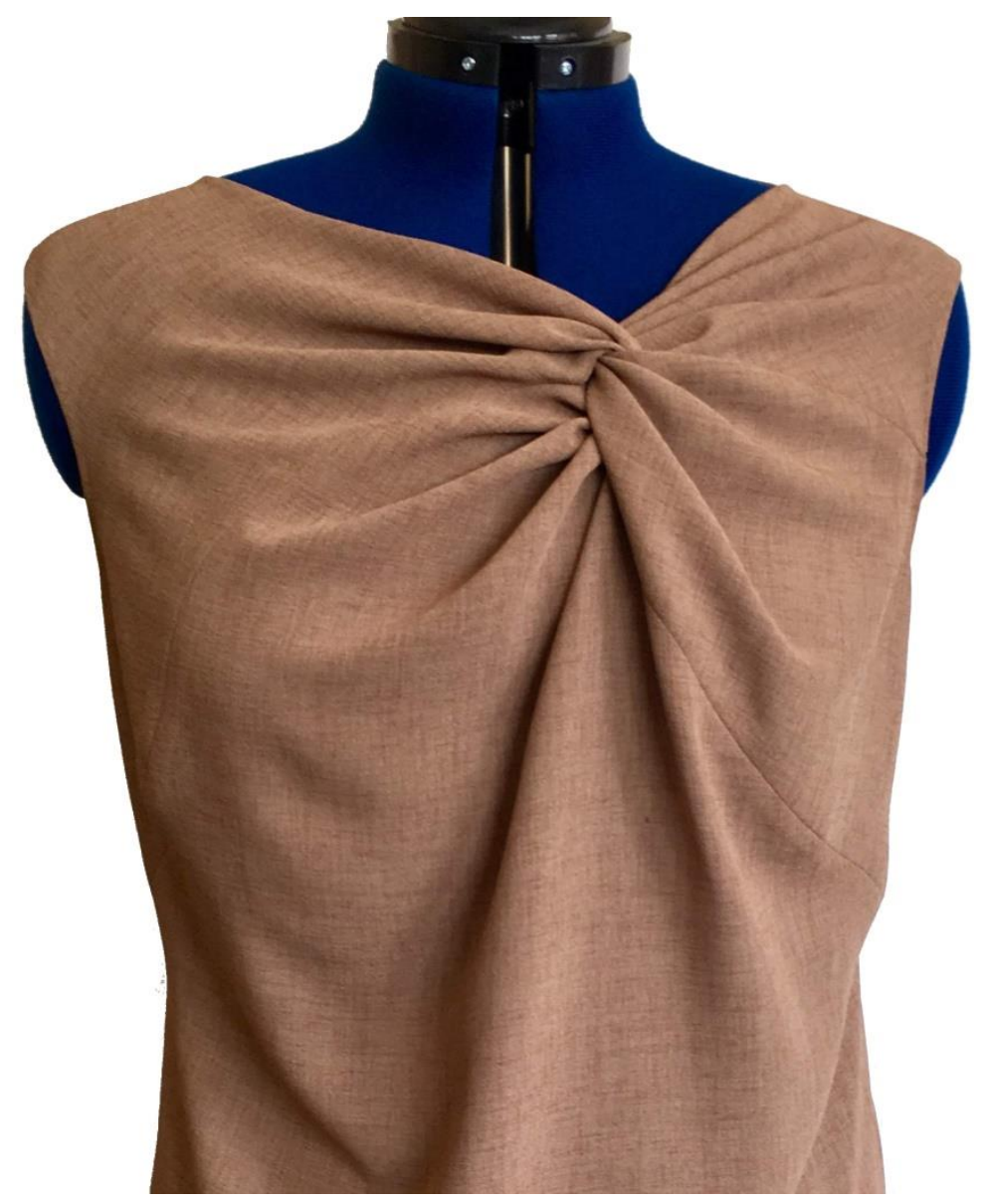

Figure 1. Design of a lady's dress with twist knot drapery

IRTIIE Vol. 7, No. 1, 2019 ISSN 1314-8788 (print), ISSN 1314-8796 (online), doi: 10.15547/artte.2019.01.002 


\section{ARTIIE

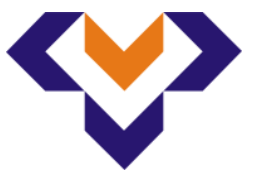

Ipplied Resererr'ches in Technics, Technologies ind Bduration

Journal of the Faculty of Technics and Technologies, Trakia University https:///ites.google.com/a/trakia-uni.bg/artte/

Figure 2 presents the pattern making in the front of the dress constructional base. The neck opening is formed with an arc. The circle of the twit knot with diameter $D=4,15 \mathrm{~cm}$ is located under neck opening in the left front and connected with the curve of the neckline with a point, which divides the neckline in Golden ratio proportion. For facilitating of constructing the bust darts are rotated in the points of intersection between side seams and waist line. A decorative and constructive seam, which divides the front in two pieces, is drawn with a curved line between the point of connection of the circle of knot with neckline and the point of intersection of the left side seam and waist line. It is the seam of connection of both twisted pieces. The seam of drapery fixing in the bigger front piece is drawn with a curved line between the point of intersection of the right side seam and waist line and the center of the circle of the knot. The seam of drapery fixing in the smaller front piece is drawn with a straight line between the left armhole and the center of the circle of the knot. A second circle is drawn with the same center of the knot circle, but with diameter which is half of the dimeter of the knot. The lines, which determine the places of divisions for volume for drapery, are tangents to the smaller circle. They start from the arm holes and the apexes of the bust darts.

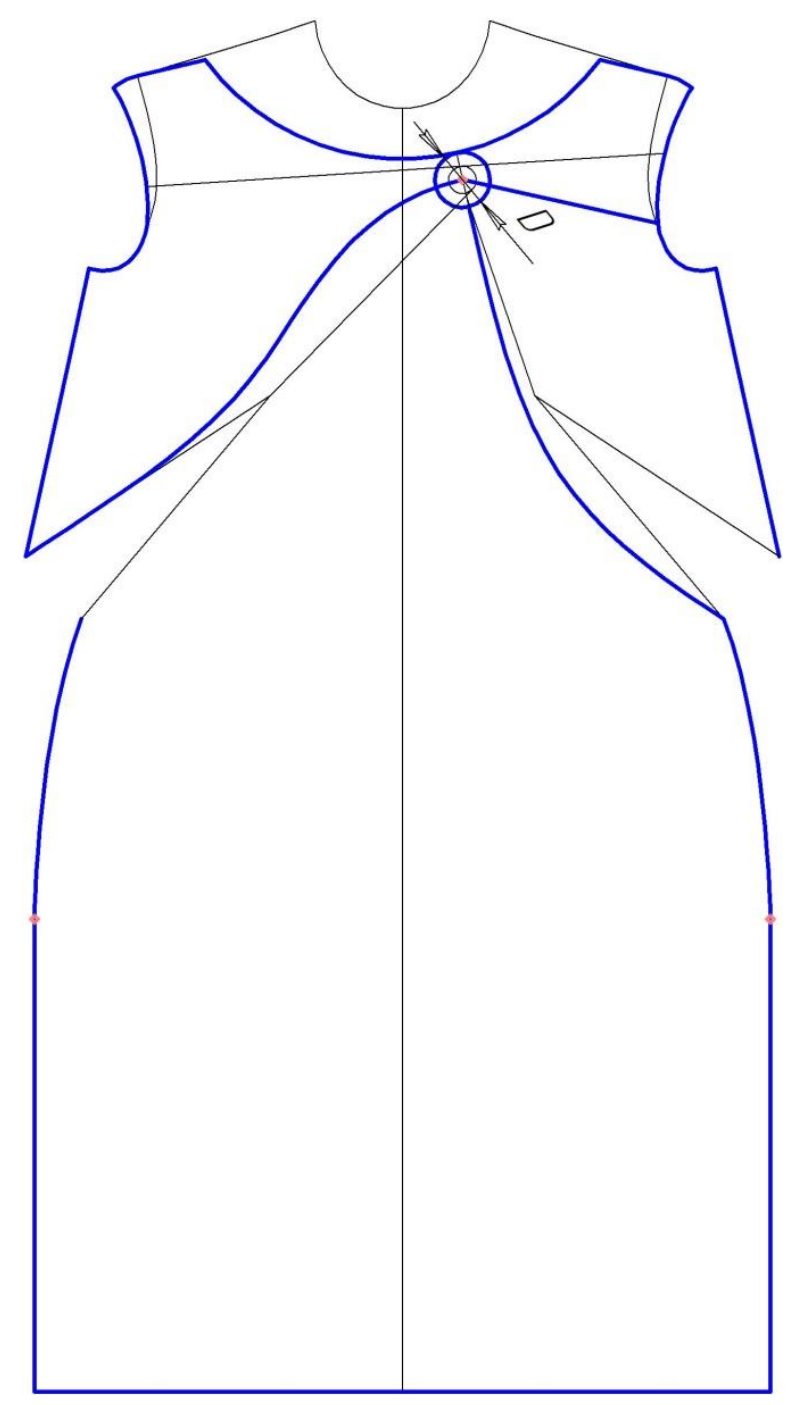

Figure 2. Constructing of twist knot drapery. The circle of the knot, seam of connection of both draped pieces, seams of drapery fixing, and lines for divisions for volume for drapery

IRTIIE Vol. 7, No. 1, 2019 ISSN 1314-8788 (print), ISSN 1314-8796 (online), doi: 10.15547/artte.2019.01.002 


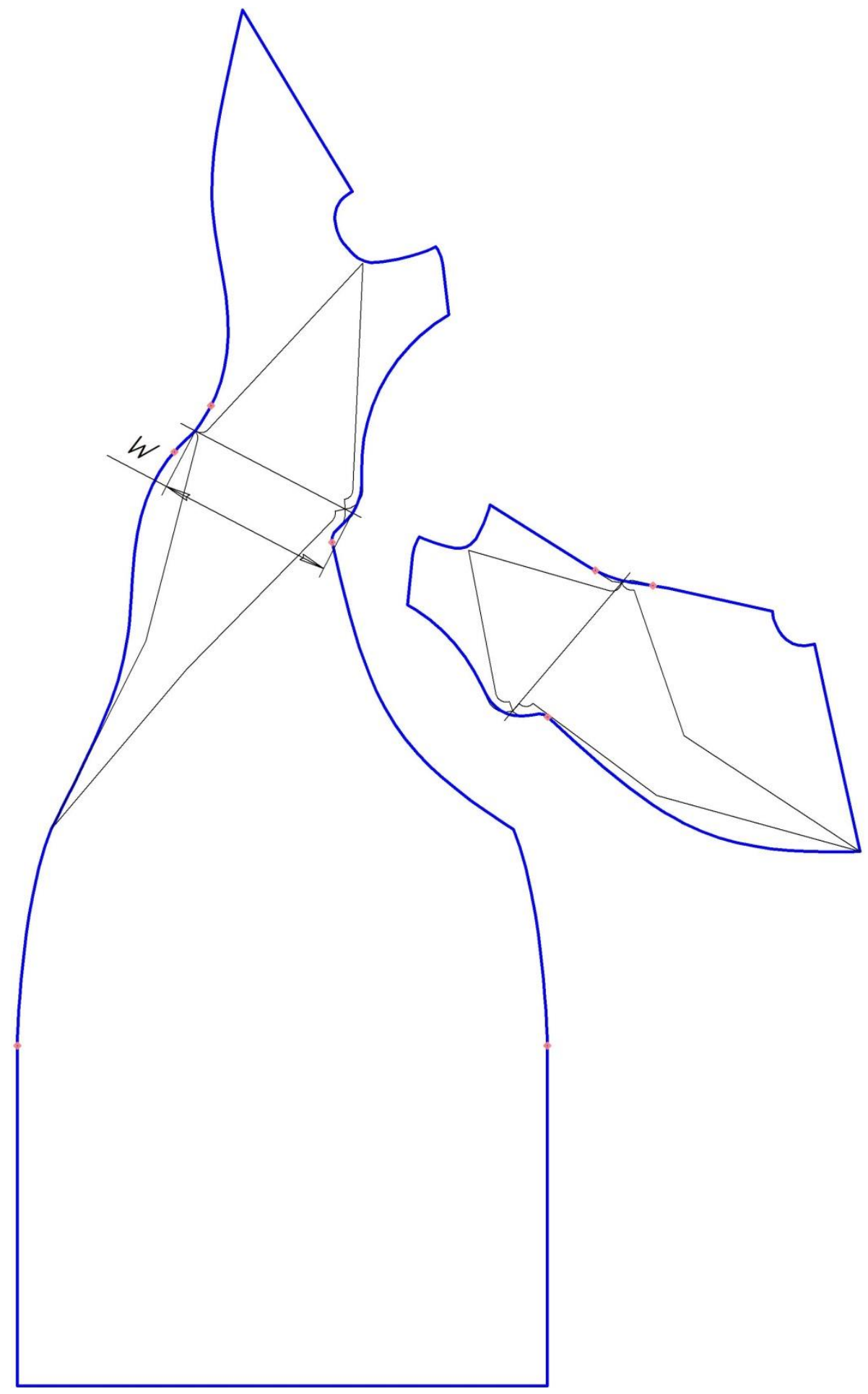

Figure 3.

The design of patterns with openings for volume of drapery and placement of the draped parts of pieces in diagonal direction 


\section{IRITIE}

Figure 3 shows the design of patterns after openings for volume of drapery $W=16,5 \mathrm{~cm}$, as the parts of pieces are open in divisions (including bust darts) around waist points on sides seams and points of dividing lines connection with armholes. The drapery is with decorative and constructive function because the bust darts are rotated and included in the openings for drape volume. After that the parts of the draped pieces are connected each other on lines in diagonal directions, which determine the places of twisting. The lines have to be in diagonal direction because the places of twist have to be cut in skew direction.

Figure 4 presents the design of the lady's dress, shown in Figure 1, realized from knitted fabrics. The pattern making of this dress uses the same geometric construction like the one from Figure 1, but with new mathematical dependence for calculating of the diameter of the knot on the base of the width of the draped pieces in the place of twist. A new investigation is made about measurements of twist knot drapery in clothing from knitted fabrics. On the base of results of the new investigation, which is the same like this in [1], formulas (3) and (4) are obtained. With a dependence the width of the draped pieces in the place of twist is determined on the base of the diameter of the knot - formula (3), or with a dependence the diameter of the knot is determined on the base of width of the draped pieces in the place of twist - formula (4):

$$
\begin{aligned}
& W=6,5 . D-20, \\
& D=0,14 . W+3,5,
\end{aligned}
$$

where $\mathrm{W}, \mathrm{cm}$ is the width of the draped pieces in the place of twist and $\mathrm{D}, \mathrm{cm}$ - the diameter of the knot.

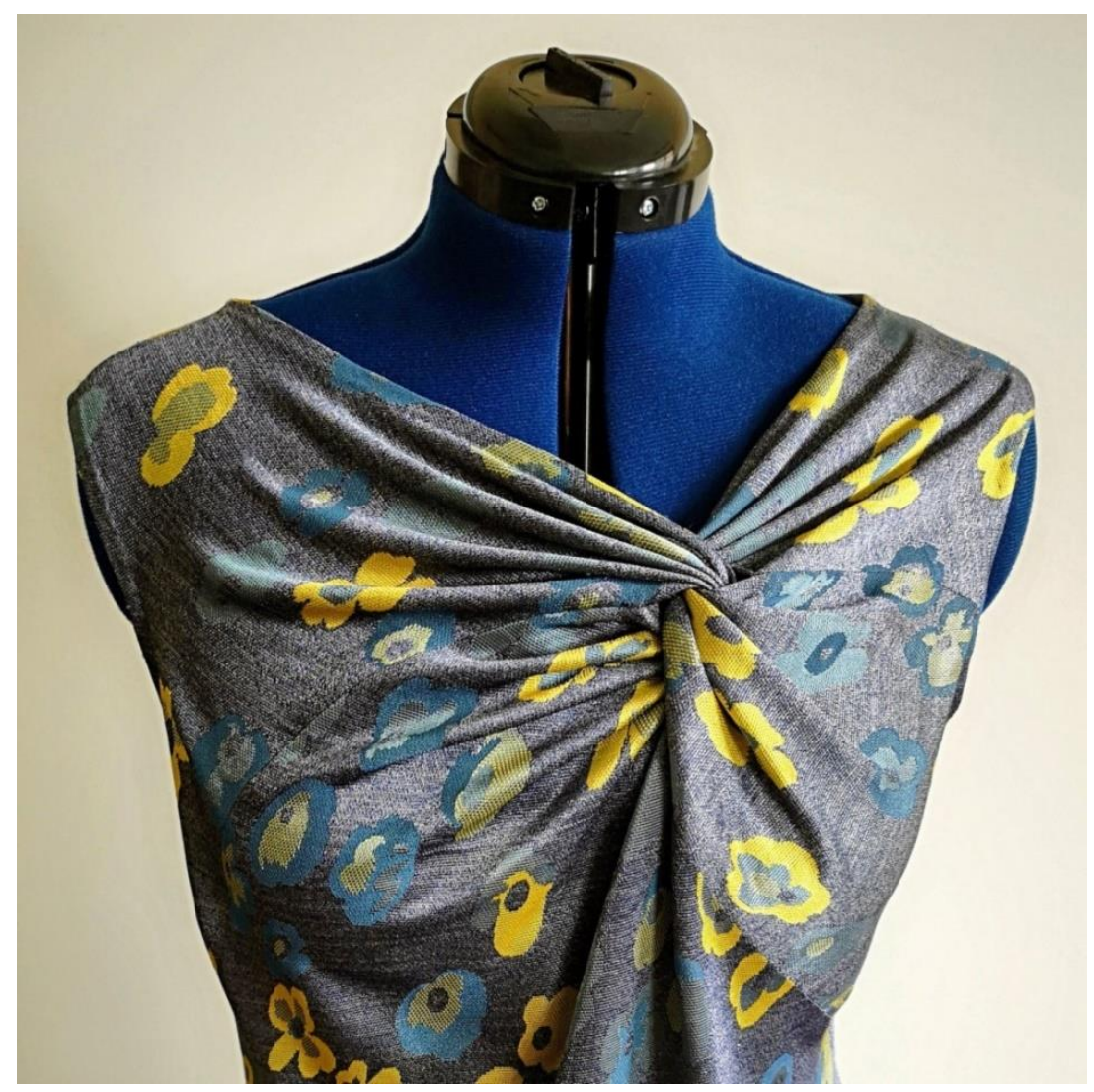

Figure 4. Fashion design like presented in Figure 1, realized with a knitted fabric

IRTIIE Vol. 7, No. 1, 2019 ISSN 1314-8788 (print), ISSN 1314-8796 (online), doi: 10.15547/artte.2019.01.002 


\section{ARTTIE $Y$}

Ipplied Resseirlores in Technics, Technologies and Educration

Journal of the Faculty of Technics and Technologies, Trakia University https://sites.google.com/a/trakia-uni.bg/artte/

In pattern making of the lady's dress, presented in Figure 4, formula (4) is used and the diameter of the knot $D=5,88 \mathrm{~cm}$ is calculated on the base of the width of the draped pieces in the place of twist $W=17,0 \mathrm{~cm}$, the smaller width according to the investigation. It is connect with the design idea for harmony between the volume of twist knot drapery and the Golden ratio proportion of its location.

Figure 5 presents a comparison between both ladies' dresses with one and the same design with twist knot drapery, but made with different fabrics - woven in Figure 1 and knitting in Figure 4. The comparison shows that the drapery in the dress from knitted fabric (in color of blue with floral ornaments) is more soft and fine, and with bigger number of folds than the drape in the dress from woven fabric (in color of golden brown) in which the folds are with smaller number but more intensive and not too soft.

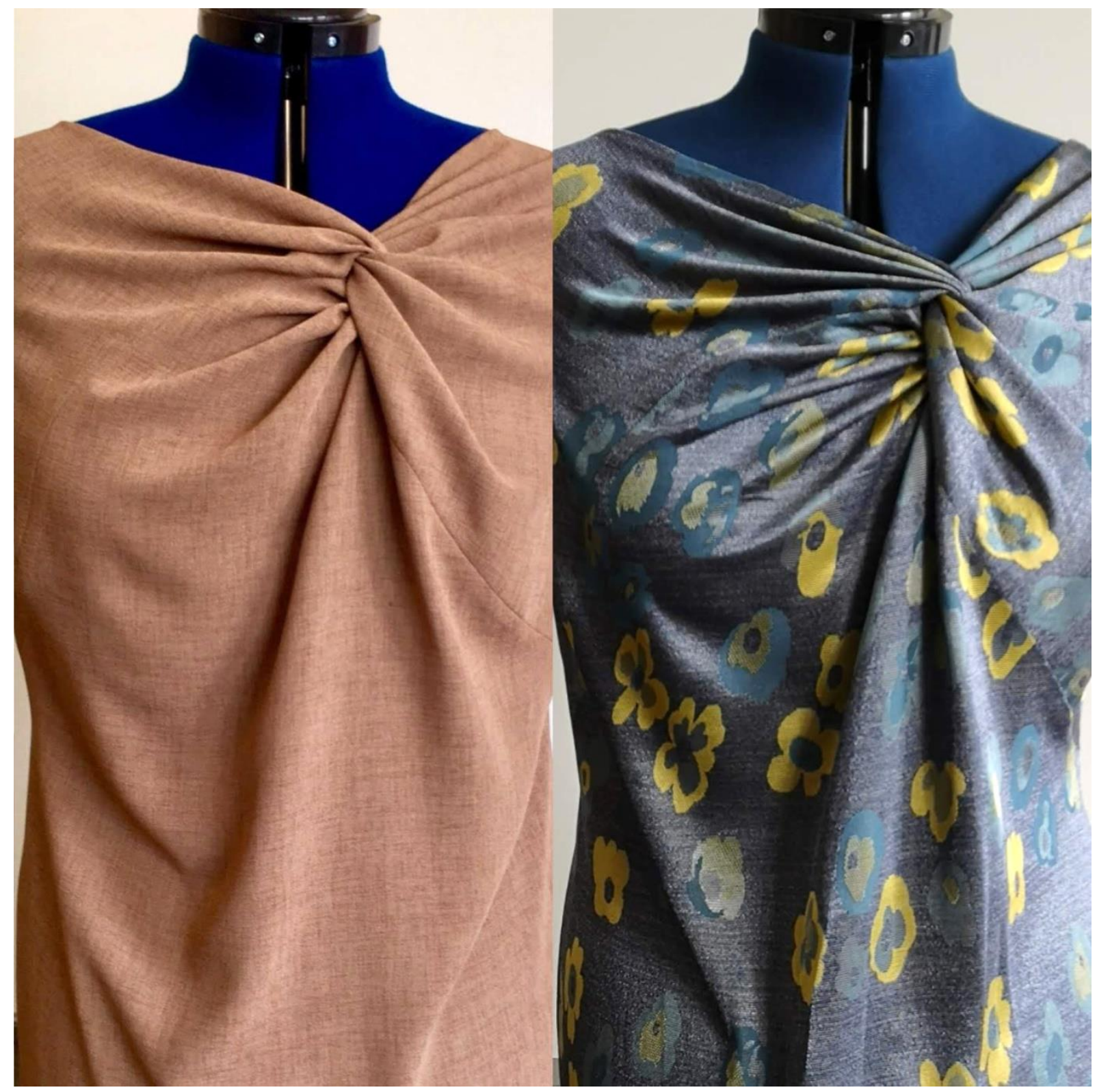

Figure 5. One and the same design realized by knitted fabric (golden brown) and woven fabric (blue with floral ornaments)

IRTIIE Vol. 7, No. 1, 2019 ISSN 1314-8788 (print), ISSN 1314-8796 (online), doi: 10.15547/artte.2019.01.002 


\section{IRTIIE

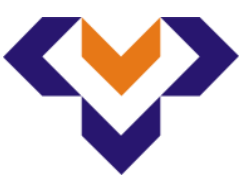 \\ Ipplied Resseirlohes in Technics, Technologies and Educration \\ Journal of the Faculty of Technics and Technologies, Trakia University https://sites.google.com/a/trakia-uni.bg/artte/}

\section{FASHION AND PATTERN DESIGN OF A LADY'S DRESS WITH TWISTED DRAPERY}

Figure 6 presents a lady's dress with twisted drapery, which asymmetrically divided the neckline in Golden ratio proportion [5]. The fashion design is based on replacement of the twist knot drapery from the gown, shown in Figure 1, with twisted drape.

The pattern design is shown in Figures 7 and 8.

The systemized approach of pattern making is presented in details in [5]. The systematization is a result of dependence (5):

$$
W=0,4 . H-2,65 \text {, }
$$

where $\mathrm{W}, \mathrm{cm}$ is the width of the twisting or the width of rectangles of twisting; $\mathrm{H}, \mathrm{cm}$ - the height of drapery or the height of the rectangles of twisting.

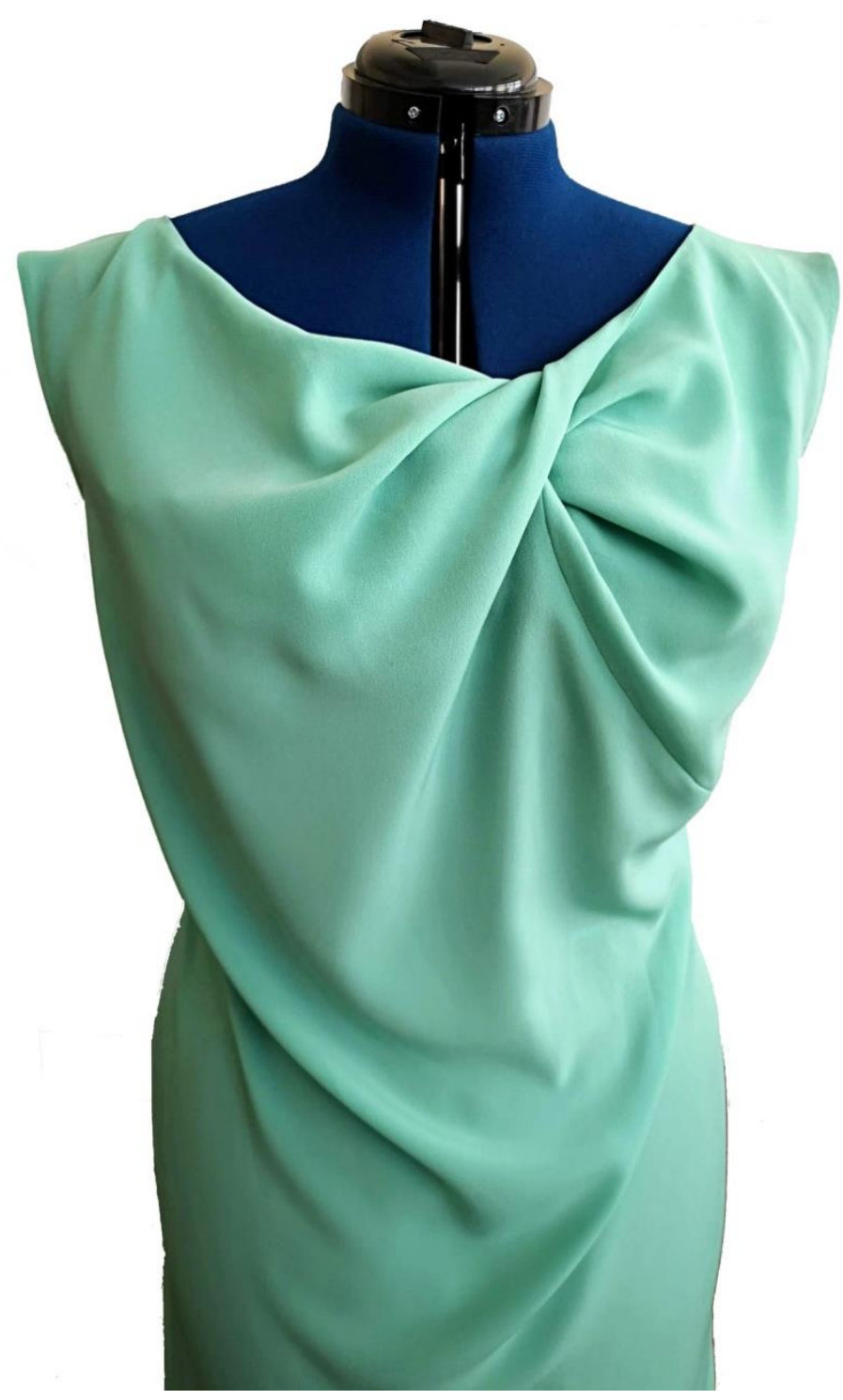

Figure 6. Design of a lady's dress with twisted drapery, transformed variant of the gown with twist knot drape, shown in Figure 1

IRTIIE Vol. 7, No. 1, 2019 ISSN 1314-8788 (print), ISSN 1314-8796 (online), doi: 10.15547/artte.2019.01.002 


\section{ARTIIE

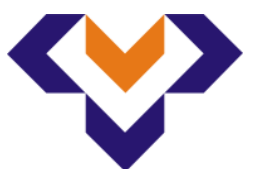

Ipplied Resererr'ches in Technics, Technologies ind Bduration

Journal of the Faculty of Technics and Technologies, Trakia University https:///ites.google.com/a/trakia-uni.bg/artte/

Figure 7 presents the transformation of the front piece of the lady's dress, prepared for design with twist knot drapery, shown in Figure 1, in one for design with twisted drapery. The seam of fixing of twisted drapery in Figure 7 is the seam of connecting of draped pieces of twist knot drapery in Figure 2. In the pattern making in Figure 7 the difference with this in Figure 2 are the lines of dividing for drapery which are drawn between the seam of fixing of twisted drapery in the center of place of drape $(4,0-5,0 \mathrm{~cm}$ under the neckline) and the apexes of bust darts.

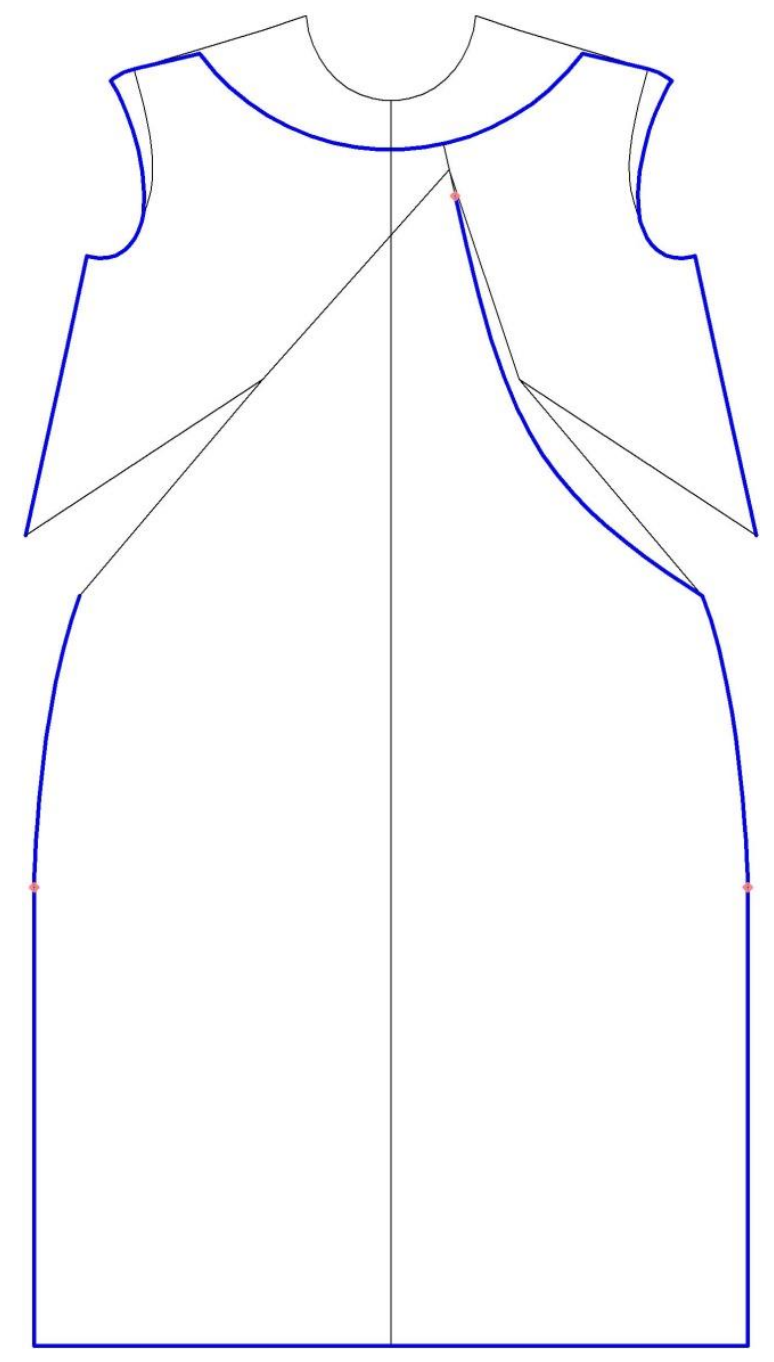

Figure 7. Constructing of twisted drapery. The place of twisting on the seam of drapery fixing and lines of dividing of pieces for drapery

Figure 8 shows the patterns design after additional openings for volume of drapery, as the parts of pieces are open in divisions (including bust darts) around waist points on sides seams. The drapery is with decorative and constructive function because the bust darts are rotated and included in the openings for drape volume. The openings and the place of drapery determine the height of drapery $\mathrm{H}$. For presented design of lady's dress with twisted drape the height of drapery $\mathrm{H}=24,0 \mathrm{~cm}$ is chosen. The width of twisting $\mathrm{W}=6,95 \mathrm{~cm}$ is calculated with the use of dependence (5). In both pieces with the width of twisting $\mathrm{W}$ and the height of drapery $\mathrm{H}$ rectangles are drawn, which form the place of twisting.

IRTIIE Vol. 7, No. 1, 2019 ISSN 1314-8788 (print), ISSN 1314-8796 (online), doi: 10.15547/artte.2019.01.002 


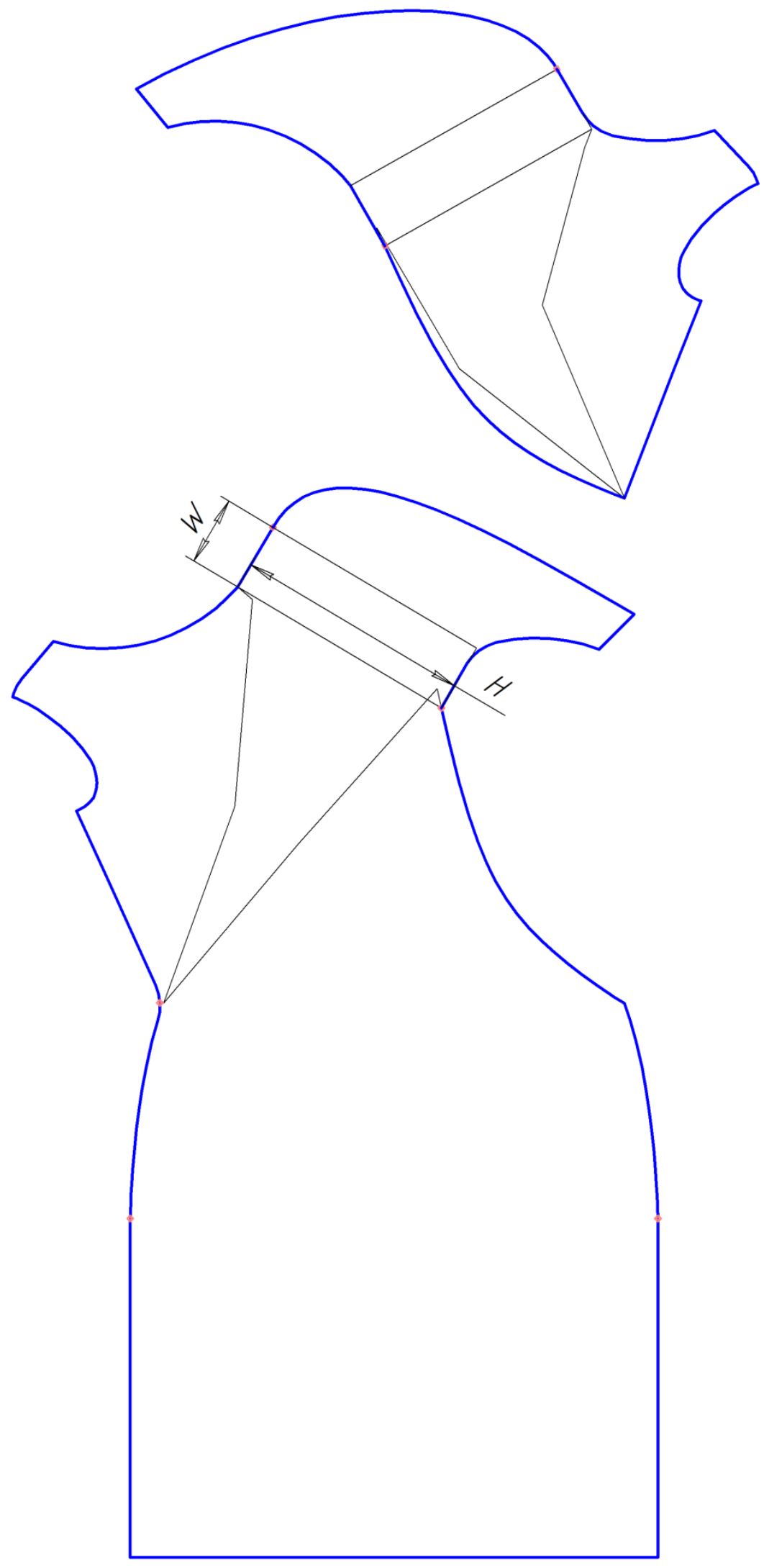

Figure 8. The design of patterns with openings for volume of drapery and place of twisting IRITIE Vol. 7, No. 1, 2019 ISSN 1314-8788 (print), ISSN 1314-8796 (online), doi: 10.15547/artte.2019.01.002 


\section{ARTTIE $Y^{2}$}

Ipplied Resseirlores in Technics, Technologies and Educration

Journal of the Faculty of Technics and Technologies, Trakia University https://sites.google.com/a/trakia-uni.bg/artte/

The Golden proportion for location of twisting are in harmony for every size of $\mathrm{H}$ between 15,0 and $30,0 \mathrm{~cm}$, the min and max heights for this type of drape, because twisted pieces don't need double openings for volume like twist knot, and max height for twisted drapery is smaller than double min width for twist knot drape. The volume for drapery is determined by width of draped place for twist knot and height of draped place for twisted drape.

Dependence (5) is valid for clothing from woven fabrics. The methodology of the study of obtaining of formula (5) can be used for obtaining of formula, valid for knitted fabrics.

Figure 9 presents a comparison between the lady's dress with twist knot drape, shown in Figure 1, and its transformed variant with twisted drapery, presented in Figure 6. The twisted drape (in color of green) is more free and gives more variants of draping if the drapery is asymmetrically situated than the twist knot drape (in color of golden brown).

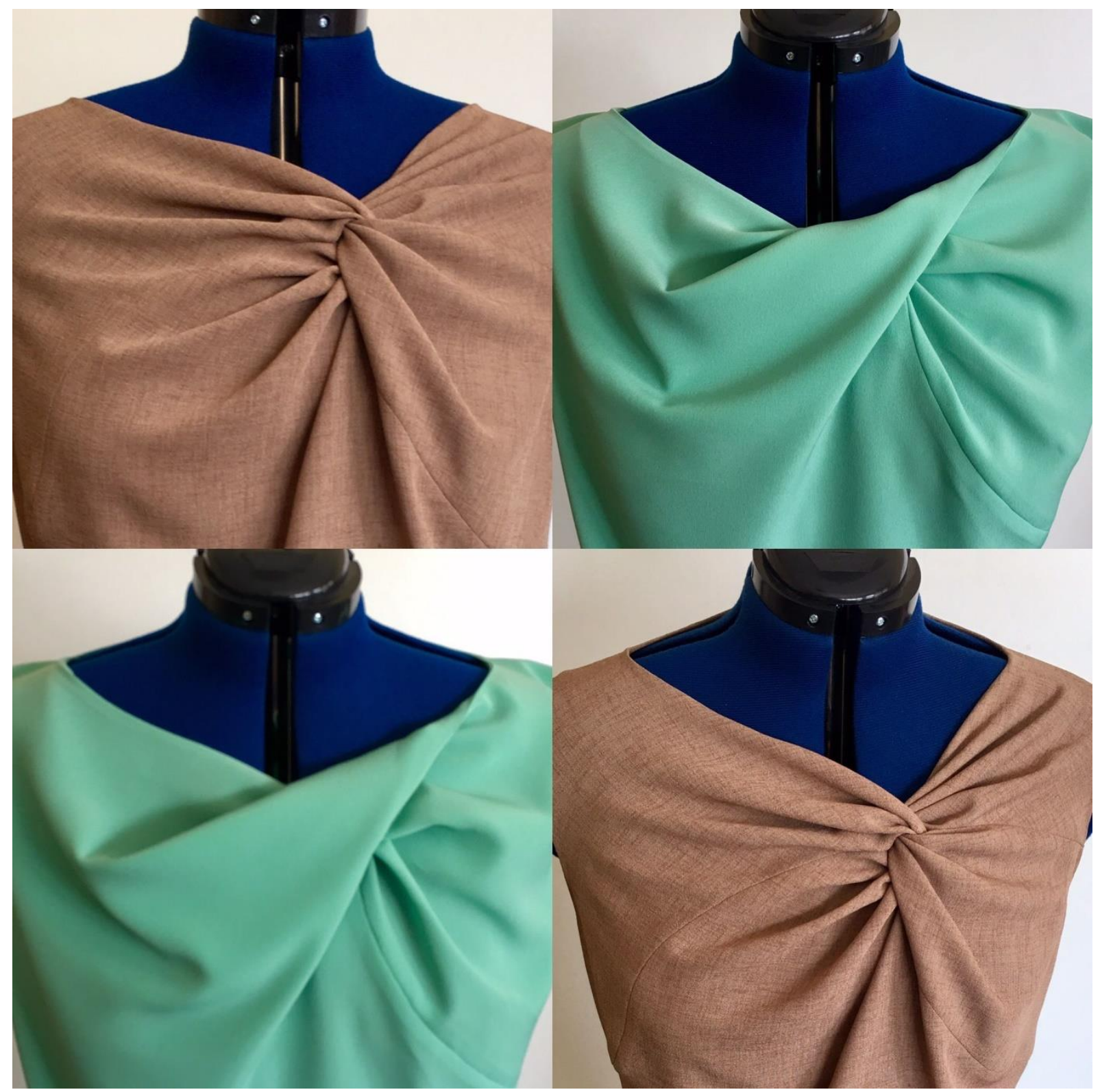

Figure 9. Comparison between the lady's dress with twist knot drape (golden brown), shown in Figure 1, and its transformed variant with twisted drapery (green), presented in Figure 6

IRTIIE Vol. 7, No. 1, 2019 ISSN 1314-8788 (print), ISSN 1314-8796 (online), doi: 10.15547/artte.2019.01.002 


\section{IRTIIE Ipplied Researroches in Technics, Technologies and Bduration Journal of the Faculty of Technics and Technologies, Trakia University https://sites.google.com/a/trakia-uni.bg/artte/}

\section{FASHION AND PATTERN DESIGN OF A LADY'S DRESS WITH FREE DRAPERY}

Figure 10 presents a lady's dress with asymmetrical free drapery. The fashion design is based on replacement of the twist knot drapery from the gown, shown in Figure 1, and replacement of the twisted drape from the dress, presented in Figure 6, with free one. The pattern design is shown in Figures 11 and 12.

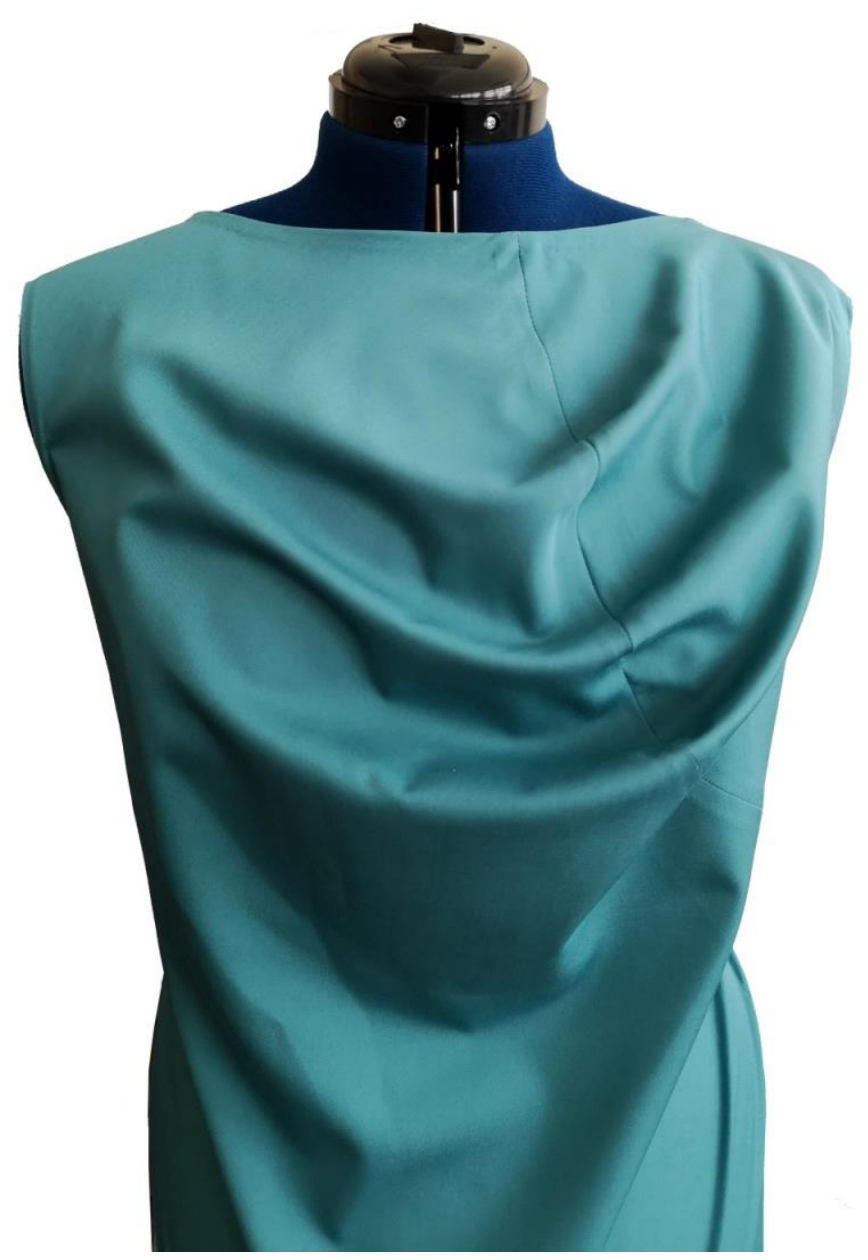

Figure 10. Design of a lady's dress with asymmetrical free drapery, transformed variant of the gowns with twist knot drape, shown in Figure 1, and twisted drapery, presented in Figure 6

Figure 11 presents the transformation of the front piece of the lady's dress, prepared for design with twist knot drapery, shown in Figure 1, or the front piece of the lady's gown, a base of design with twisted drape, presented in Figure 6, in one for design with free drapery. The seam of forming of free drapery in Figure 11 is the seam of connecting of draped pieces of twist knot drapery in Figure 2, and the same of fixing of twisted drapery in Figure 7, which divides the neckline in Golden proportion. In the pattern making in Figure 11 the difference with these in Figures 2 and 7 is the curved line between shoulders, which shows direction of free drapery. The curve crosses the seam of forming of free drapery in the middle between the neckline and the apex of the left bust dart.

IRTIIE Vol. 7, No. 1, 2019 ISSN 1314-8788 (print), ISSN 1314-8796 (online), doi: 10.15547/artte.2019.01.002 


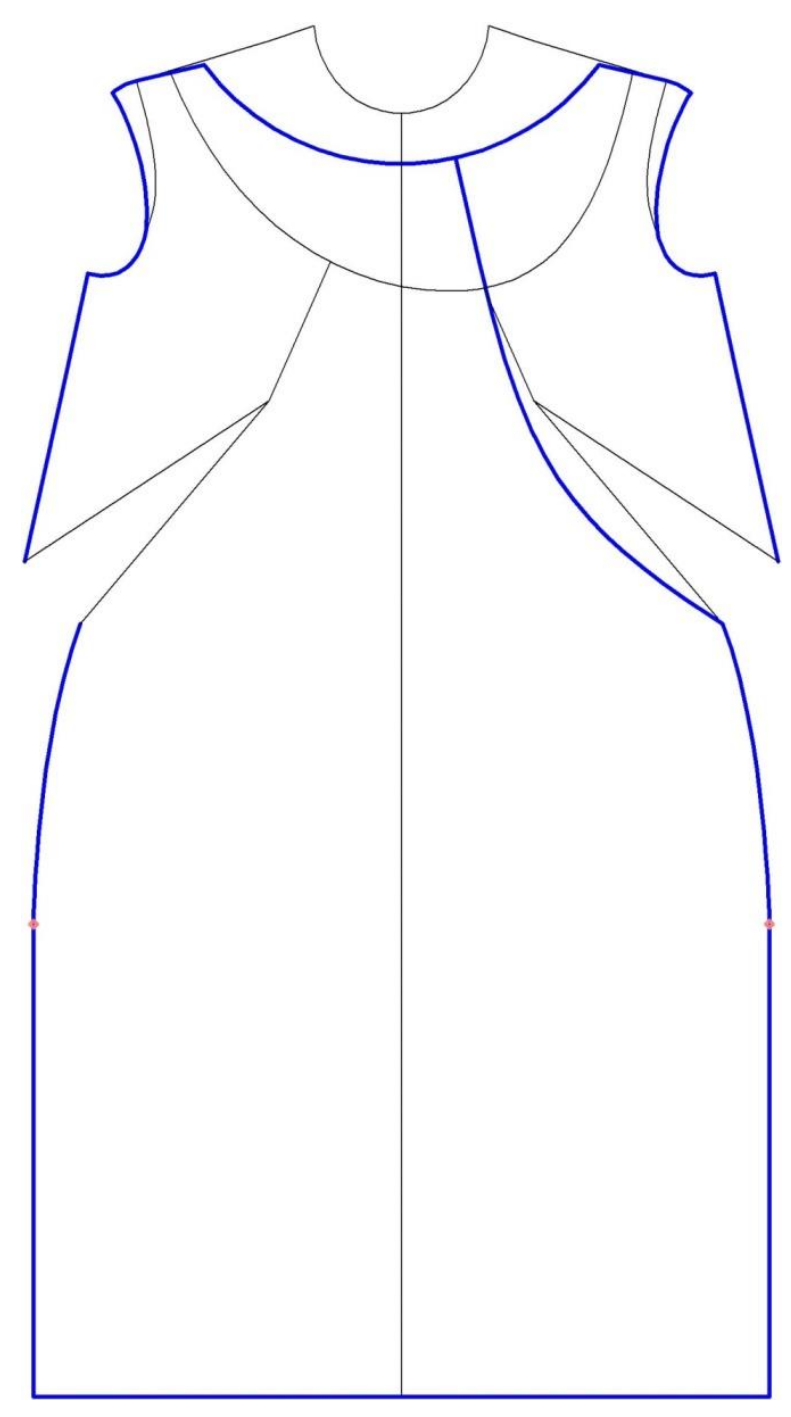

Figure 11. Constructing of free drapery.

The seam of forming of drape folds and the line of drapery direction

Figure 12 shows the design of patterns for free drapery. For volume of the drape the both pieces are divided in the segments of the drapery direction line. The volume of drapery is result from rotation of the divided parts of pieces around the points of intersection of the drapery direction line and shoulders and the insertions of both bust darts in the openings. The bust darts insertions determine the design and constructive function of the drapery. The size of the openings for volume of drape folds depends on the design idea. In example in Figure 12 it is a little bigger than the distance between the neckline and the drapery direction line. Of course the bigger opening leads to richer drapery with bigger number of folds. In the places of openings the contours of the seam of forming are designed with curved lines. Second variant of this pattern making is possible in which the both front patterns are connected in the places of openings for volume and are united in one piece. In result an asymmetric free drapery is possible in one pattern, formed by two decorative and constructive seams over and under the place of drape. 


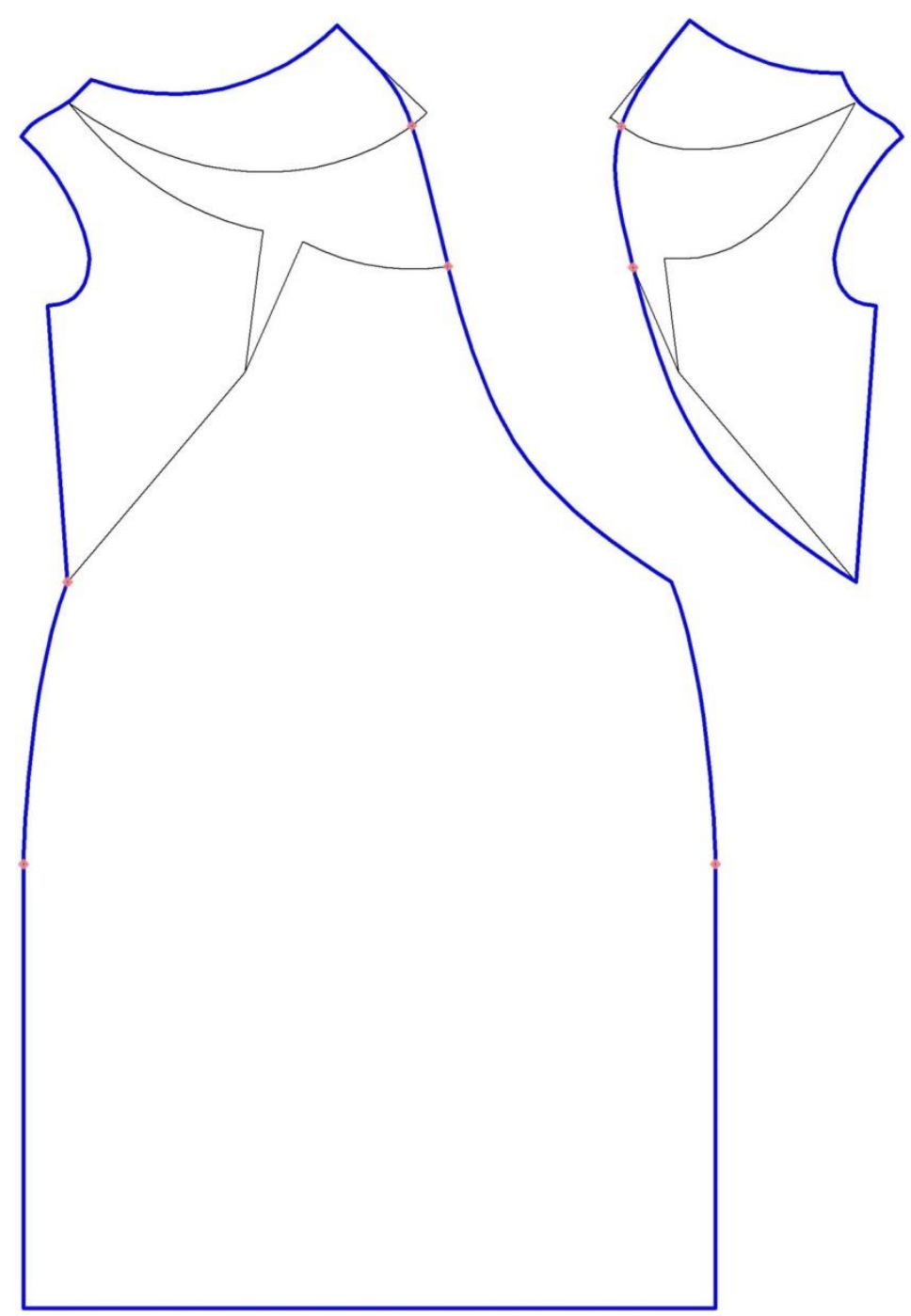

Figure 12. The design of patterns with openings for volume of drapery and seam of free drape forming

\section{CONCLUSIONS}

With presented way of transformation new designs of draped ladies' dresses are easy and successfully created. Every of the basic three types of drapery with decorative and constructive function: twist knot, twisted and free ones can be changed with other two types. The facilitating of design and pattern making is result not only that transformations are made on one basic model, but also that systemized approaches of constructing of twist knot and twisted draperies are used.

\section{ACKNOWLEDGEMENTS}

The work is supported by the scientific project 2.FTT/ 2016 'Investigation of the Fashion Design and Pattern making of 3D Elements in Ladies' Clothing' funded by the Faculty of Technics and Technologies of Yambol, Trakia University of Stara Zagora, and the Fund of the National budget for scientific research in higher education in Bulgaria.

IRTIIE Vol. 7, No. 1, 2019 ISSN 1314-8788 (print), ISSN 1314-8796 (online), doi: 10.15547/artte.2019.01.002 


\section{REFERENCES}

[1] Kazlacheva Z., Ilieva J. (2018). An investigation of Design of Twist Knot Drape Clothes. The Aegean International Textile and Advanced Engineering Conference AITAE 2018, 57 September 2018, Lesvos, Greece, IOP Conf. Ser.: Mater. Sci. Eng. 459 (2018) 012079. doi:10.1088/1757-899X/459/1/012079.

[2] Kazlacheva Z. (2017). An Investigation of Application of the Golden Ratio and Fibonacci Sequence in Fashion Design and Pattern Making. $17^{\text {th }}$ World Textile Conference AUTEX 2017 - Textiles - Shaping the Future, 29-31 May 2017, Corfu, Greece, IOP Conf. Series: Materials Science and Engineering 254 (2017) 172013. doi:10.1088/1757899X/254/17/172013.

[3] Nakamichi T. (2010). Pattern Magic. London, UK, Laurence King, 2010, ISBN 9781856697057.

[4] Hill, T. \& Lewicki, P. (2007). Electronic Statistics Textbook. Available: http://statsoft.com/textbook/stathome.html [2007-2017].

[5] Kazlacheva Z. (2019). Pattern Design of Twisted Draperies with Decorative and Constructive Function. ARTTE Applied Researches in Technics, Technologies and Education, Vol. 7, No. 1, pp. 1-9. doi: 10.15547/artte.2019.01.001. 